\title{
Heavy Metal Contamination of Well Water in the Kipushi Mining Town (Democratic Republic of Congo)
}

\author{
Bamba Bukengu Muhaya ${ }^{1}$, Rachel Mulunda Numbi ${ }^{2}$, Francois Toto Lubala ${ }^{2}$, Joel Bacirheba Mugisho ${ }^{2}$ and \\ Dieudonne Kabumana Tshibanda ${ }^{1}$ \\ 1. Department of Chemistry, Faculty of Science, Lubumbashi University, Lubumbashi 1825, Democratic Republic of Congo \\ 2. Department of Geology, Faculty of Science, Lubumbashi University, Lubumbashi 1825, Democratic Republic of Congo
}

\begin{abstract}
Concentrations of eleven heavy metals (Al, $\mathrm{Cd}, \mathrm{Co}, \mathrm{Cu}, \mathrm{Cr}, \mathrm{Fe}, \mathrm{Mn}, \mathrm{Mo}, \mathrm{Ni}, \mathrm{Pb}$ and $\mathrm{Zn}$ ) and pH determination in water from nine spade-sunk wells of 2-15 meter depth, five drilled wells of 30-72 meter depth, and two water supply faucets in the Kipushi mining town, south-east of the Democratic Republic of Congo, were investigated from February to July 2011. The results were compared with the World Health Organization (WHO) drinking water $\mathrm{pH}$ and heavy metal guidelines. Mean concentrations of $\mathrm{Pb}$ in water from four spade-sunk wells and three drilled wells, those of $\mathrm{Al}$ and $\mathrm{Fe}$ in water from four and two spade-sunk wells, and those of Cd in water from four drilled wells were higher than the WHO drinking water maximum permissible contaminant limits of $0.01 \mathrm{mg} / \mathrm{L}, 0.2$ $\mathrm{mg} / \mathrm{L}, 0.3 \mathrm{mg} / \mathrm{L}$ and $0.003 \mathrm{mg} / \mathrm{L}$ respectively, probably due to the mining activities carried out in Kipushi for about 90 years. The $\mathrm{pH}$ mean values of water from five spade-sunk wells and three drilled wells were lower than the WHO drinking water $\mathrm{pH}$ optimum of 6.5-9.5, suggesting that the water from those eight wells was not conform to the chemical quality of water for human consumption.
\end{abstract}

Key words: Heavy metals, pH, drinking water, well water, WHO guidelines, Kipushi.

\section{Introduction}

The Democratic Republic of Congo (DRC) has the most important hydrologic resources of the African continent, but it nowadays faces an acute crisis of drinking water supply. Actually, many urban and rural areas in the country are facing drastic shortage of drinking water. According to statistics published by the Congolese Ministry of Energy and the United Nations Environmental Program (UNEP), the DRC national rate of drinking water service which was $69 \%$ in 1990 , fell down to $22 \%$ in 2005 before currently rising again to $26 \%$ [1].

In a technical report ("water issues in DRC: challenges and opportunities") [2], the UNEP showed the major challenges concerning drinking water in urban, out-of-town and rural areas in DRC. According to that UN institution [2], the situation is due to:

Corresponding author: Bamba Bukengu Muhaya, Ph.D., associate professor, research fields: mapping and assessing the environmental and health impacts of abandoned mines in Sub-Saharan African countries. E-mail: bbmuhaya@gmail.com.
- neglected infrastructures (one third of the water treatment plants is non-operational);

- the rate of rapid urban population growth;

- the high price of water;

- the low investment return and the low financial viability of the public services in charge of water;

- the informality of water services provision/delivery in out-of-town areas;

- the degradation of the watersheds increasing the costs of water treatments.

Social and sanitary consequences of the rupture of water services are considerable. The poorest people are concerned in a disproportional manner by the decline of the water services and the increase of water prices. Such a situation has been observed not only in rural areas but also in urban areas with rapid population expansion [2].

The Kipushi mine and its adjacent town with an estimated population of 120,000 inhabitants are located between $11^{\circ} 44^{\prime}$ and $11^{\circ} 48^{\prime}$ of latitude south and between $27^{\circ} 11^{\prime}$ and $27^{\circ} 16^{\prime}$ of longitude east, in 
the south-west at about 30 kilometers from the Lubumbashi - the capital city of the Katanga province, DRC, close to the DRC-Zambia border (Figs. 1a and $1 b)$. Its altitude is about $1,350 \mathrm{~m}$ above the sea level.

The climate is tropical humid characterized by a rainy season from October to April, with a maximum of rains in February, and a dry season from May to September. The annual mean temperature is $20.3{ }^{\circ} \mathrm{C}$ with a minimum of $11{ }^{\circ} \mathrm{C}$ in June and a maximum of $30{ }^{\circ} \mathrm{C}$ in October.

From geological point of view, the Kipushi $\mathrm{Cu}-\mathrm{Pb}-\mathrm{Zn}-\mathrm{Cd}-\mathrm{Ge}$ deposit is hosted in dolomitic and shales rocks overlying a glaciogenic diamictite (grand conglomerate) related to the Nguba Group of Neoproterozoic age. The economic minerals mainly consist of major sphalerite, chalcopyrite, pyrite and bornite with minor chalcocite, molybdenite, arsenopyrite and galena. The distribution of the ore bodies is strongly fault controlled, and/or controlled by lithological competence barriers between shales and massive dolomite reported as Kakontwe Dolomite. The deposit has a magmatic hydrothermal origin and contains major $\mathrm{Cu}, \mathrm{Zn}$ and $\mathrm{Fe}$ as chalcopyrite, bornite, sphalerite and pyrite and minor $\mathrm{Pb}$ occurring as galena [3]. In addition, low concentrations of metals such as $\mathrm{Ga}, \mathrm{Ge}, \mathrm{Se}, \mathrm{Ni}, \mathrm{Ag}, \mathrm{Co}, \mathrm{Cd}$, As and Mo etc., are found in the forms of renierite, arsenopyrite and molybdenite etc. [3].

Kipushi deposit was mined since 1925 by the Union Miniere du Haut-Katanga (UMHK) up to 1967 and by the "Generale des Carriereset des Mines" (GECAMINES) until 2003. Kipushi Mining Company (KICO) took over the mine since 2013. The mine and town have over the years become interlinked with the tailings disposal system for concentrator running very close to habitations. From 1926 to 1993, production from the mine was approximately 60 million tons of ore with average grade of $11 \% \mathrm{Zn}, 7 \% \mathrm{Cu}$ and $5 \% \mathrm{~Pb}$.

Around the year 1935, the company put in service concentrators which used floatation to process sulfide ores. Those operations have generated huge quantities
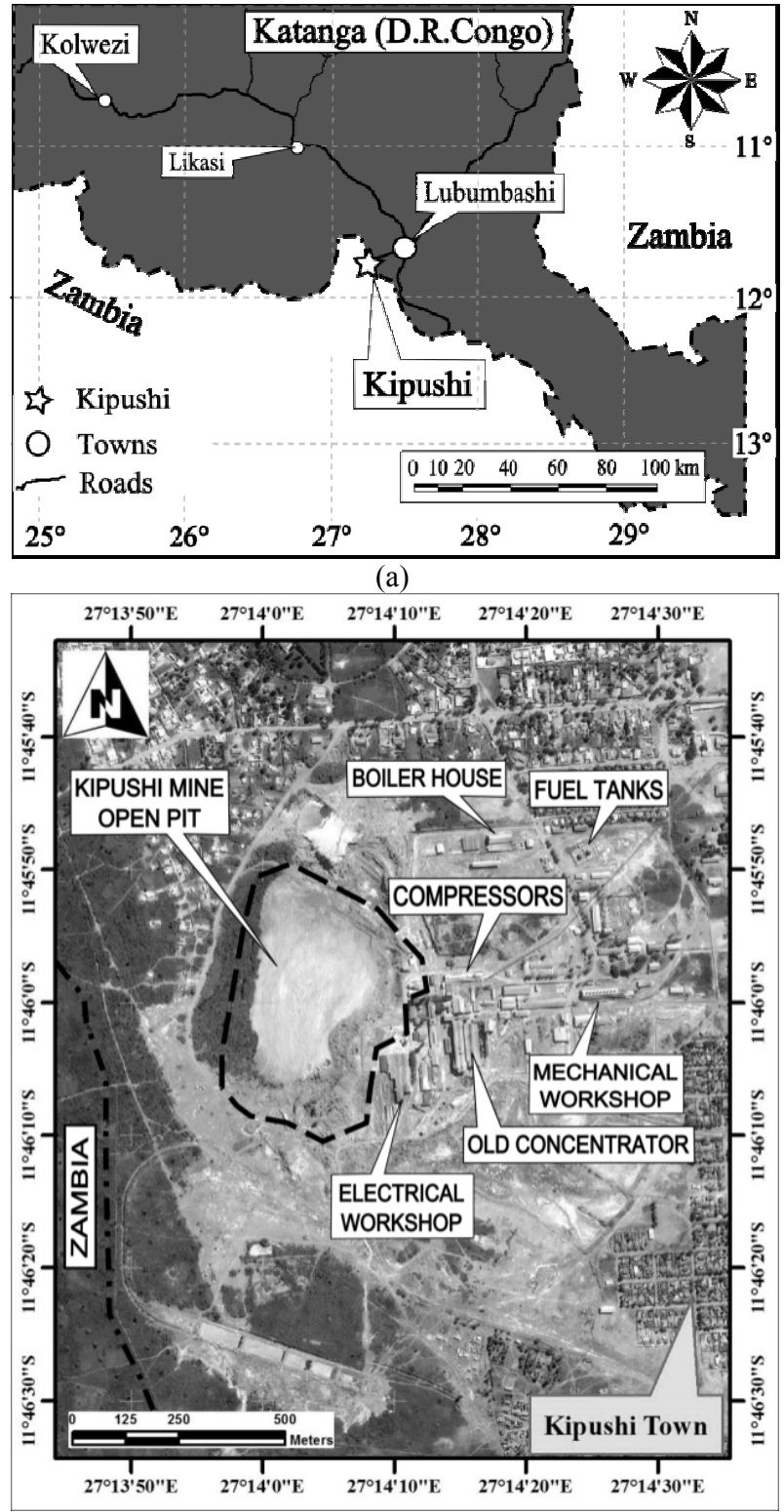

(b)

Fig. 1 (a) Location of the Kipushi studied area in southeast D.R. Congo and (b) map of the Kipushi mine layout.

of wastes under pulp form moved to artificial basins for the decantation of contained water. The progressive filling of those basins gave place to solid wastes (tailings).

The most comprehensive previous work carried out in the area was that of Kitobo et al. [4, 5], who sampled and assayed the material from dumps and impoundments and assessed their impacts on the environment. He pointed out that this material 
randomly stockpiled in river flats and sulfides minerals underwent oxidation at contact with air and water generating Acid Mining Drainage (AMD).

The aim of this study is to assess the impact of those wastes on the underground water in particular by using geochemical tools. In this respect, $\mathrm{pH}$ and heavy metal concentrations of water from spade sunk wells, drilled wells and water supply faucets in the Kipushi mining town were investigated. The results were compared with the WHO [6] $\mathrm{pH}$ optimum and heavy metal guidelines for drinking water in order to point out the level of heavy metal contamination of water used for human consumption.

\section{Material and Methods}

\subsection{Sampling Sites}

Once a month from February to July 2011, water samples were collected from two water supply faucets (EDD1 and EDD2), nine spade-sunk wells (EPA1, EPA2, EPA3, EPA4, EPA5, EPA6, EPA7, EPA8 and EPA9) of 2-15 meter depth, and five drilled wells (EPP1, EPP2, EPP3, EPP4 and EPP5) of 30-72 meter depth in the Kipushi mining town. The sampling sites are shown in Fig. 2.

The samples were collected in $50 \mathrm{~mL}$ polyethylene bottles and processed following classic protocol. Chemical analyses were performed by Robinson International in Africa laboratory in Lubumbashi. The sample codes, types and collection sites are shown in Table 1 and Fig. 2.

\subsection{Analytical Methods}

Water $\mathrm{pH}$ was determined with a $\mathrm{pH}$-meter and heavy metal concentrations in the water samples were investigated using Inductively Coupled Plasma Atomic Emission Spectroscopy (ICP-AES) after pulverization of acidic solvent and sample pre-concentration.

\section{Results and Discussion}

REGIDESO (the Congolese water supply company)
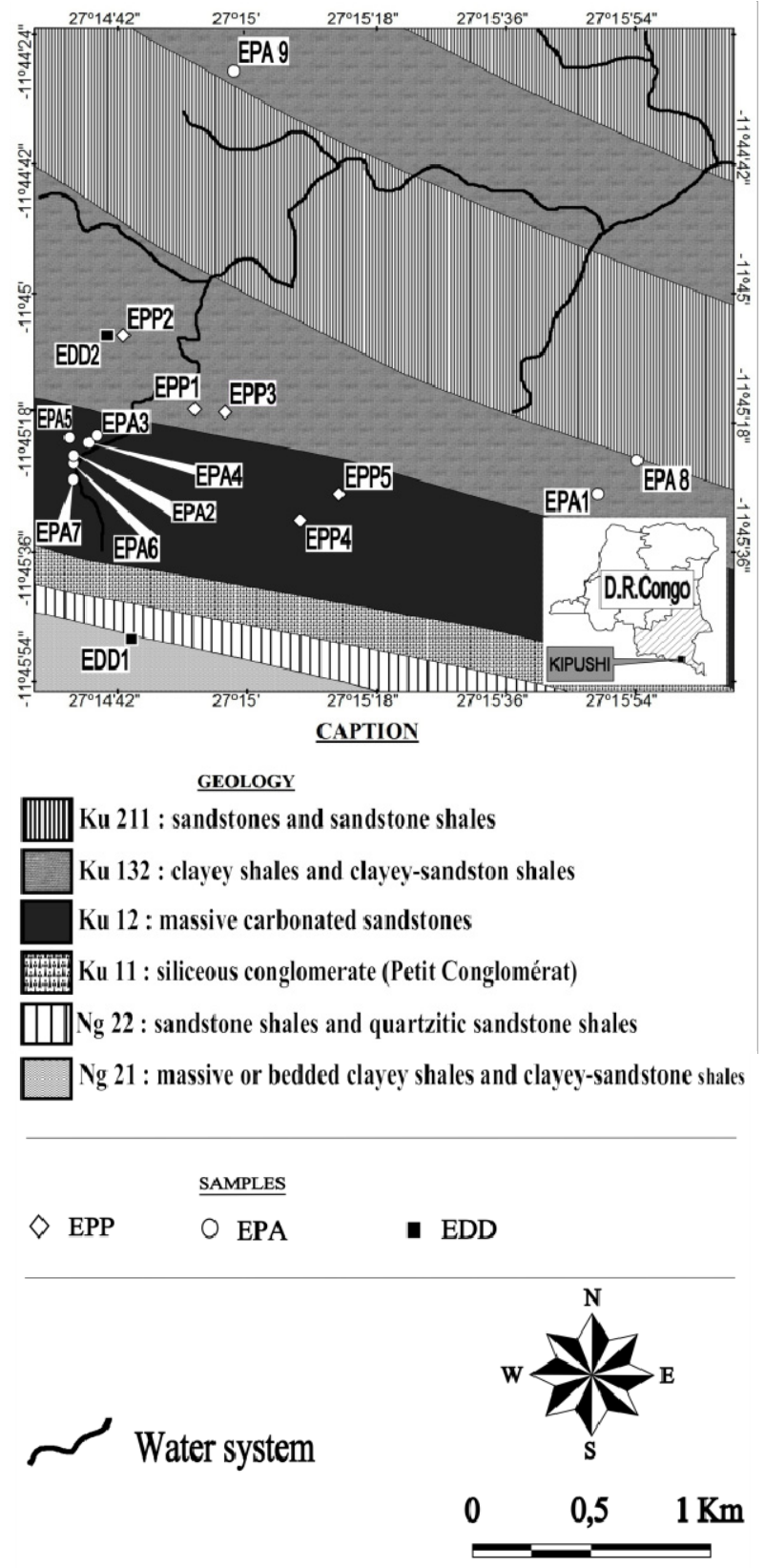

Fig. 2 Location of the sampling sites on the geological map of the Kipushi mining town.

is facing technical problems and cannot meet its customers' needs. This situation pushed the Kipushi population, including REGIDESO customers, to spade sink or drill wells in their parcels in order to get a permanent and easy access to water.

\subsection{Water $\mathrm{PH}$}

The $\mathrm{pH}$ values of faucet water (EDD1 and EDD2), those of water from spade-sunk wells EPA2, EPA3, 
Table 1 Water sample codes and types, sampling site coordinates, types and depths of various water wells in the Kipushi mining town in 2011.

\begin{tabular}{|l|l|l|}
\hline Sample code & Sample type & Sampling site coordinates and depth \\
\hline EDD1 & Faucet water & 9 B, Shituru avenue, Shituru area; water supply faucet \\
\hline EDD2 & Faucet water & Kipushi prison, Prison camp area; water supply faucet \\
\hline EPA1 & Spade-sunk well water & $\begin{array}{l}\text { 56, Shindaika avenue, Chachacha area; 15-meter deep well sunk with a spade } \\
\text { on November 11, 1981 }\end{array}$ \\
\hline EPA2 & Spade-sunk well water & Street 4, Mailamene area; 3-meter deep spade-sunk well \\
\hline EPA3 & Spade-sunk well water & 254, Street 3, Mailamene area; 4-meter deep spade-sunk well \\
\hline EPA4 & Spade-sunk well water & 1, Street 3, Mailamene area; 2-meter deep spade-sunk well \\
\hline EPA5 & Spade-sunk well water & Street 2, Mailamene area; 3-meter deep spade-sunk well \\
\hline EPA6 & Spade-sunk well water & 7, Grand Luapula avenue, Mailamene area; 10-meter deep spade-sunk well \\
\hline EPA7 & Spade-sunk well water & 4, Grand Luapula avenue, Mailamene area; 6-meter deep spade-sunk well \\
\hline EPA8 & Spade-sunk well water & Mobutu avenue, Sapin area; 15-meter deep spade-sunk well \\
\hline EPA9 & Spade-sunk well water & City area near Kipushi lake; 5-meter deep spade-sunk well \\
\hline EPP1 & Drilled and well protected well water & Mwanga school complex, Grand Luapula avenue, city area; 60-meter deep well \\
\hline EPP2 & Drilled and well protected well water & Kipushi prison, prison camp area; 30-meter deep well \\
\hline EPP3 & Drilled and well protected well water & Betty health center, Grand Luapula avenue, city area; 72-meter deep well \\
\hline EPP4 & Drilled and well protected well water & Mukuba school complex, Mobutu avenue; 60-meter deep well \\
\hline EPP5 & Drilled and well protected well water & Imani institute, Kiluba avenue; 57-meter deep drilled well \\
\hline
\end{tabular}

EPA4 and EPA9 as well as drilled wells EPP1 and EPP2 during the period of February to July 2011 are given in Tables 2-12. On the whole, they were in accordance with the WHO [6] $\mathrm{pH}$ optimum interval of 6.5-9.5 for drinking water. On the other hand, the water $\mathrm{pH}$ mean values $(5.6 \pm 0.3$ to $6.4 \pm 0.2)$ of five of the nine spade-sunk wells (EPA1, EPA5, EPA6, EPA7 and EPA8) and those $(6.1 \pm 0.1$ to $6.3 \pm 0.2)$ of three of the five drilled wells (EPP3, EPP4 and EPP5) were outside the WHO [6] $\mathrm{pH}$ optimum interval for drinking water, suggesting that the water from those eight latter wells was not suitable for human consumption with regard to its $\mathrm{pH}$.

\subsection{Heavy Metals}

The mean concentrations of heavy metals in those samples for the same period are given in Tables 2-12, and illustrated in Fig. 3.

\subsubsection{Lead $(\mathrm{Pb})$}

$\mathrm{Pb}$ levels of faucet water ranged from $0.001 \mathrm{mg} / \mathrm{L}$ to $0.47 \mathrm{mg} / \mathrm{L}$, those of water from spade-sunk wells from $0 \mathrm{mg} / \mathrm{L}$ to $0.039 \mathrm{mg} / \mathrm{L}$ and those of water from drilled wells vary between $0.001 \mathrm{mg} / \mathrm{L}$ and $0.05 \mathrm{mg} / \mathrm{L}$. With $\mathrm{Pb}$ levels equal to or higher than the WHO [6]
Table 2 Mean values and standard deviations of $\mathrm{pH}$ and $\mathrm{Pb}$ levels of supply water and well water in Kipushi in 2011, and the WHO [6] guidelines.

\begin{tabular}{lll}
\hline & \multicolumn{2}{l}{$\begin{array}{l}\text { WHO* drinking water } \mathrm{pH} \text { optimum and } \\
\text { maximum permissible } \mathrm{Pb} \text { concentration } \\
\text { limit, and } \mathrm{Pb} \text { mean concentration values } \\
\text { with standard deviation of the water samples }\end{array}$} \\
\cline { 2 - 3 } & $\mathrm{pH}$ & \multicolumn{1}{c}{$\mathrm{Pb}(\mathrm{mg} / \mathrm{L})$} \\
\hline WHO* & $6.5-9.5$ & 0.01 \\
guidelines & & \\
water sample & & $0.002 \pm 0.001$ \\
EDD1 & $7.4 \pm 0.1$ & $0.014 \pm 0.019$ \\
EDD2 & $7.2 \pm 0.1$ & $0.007 \pm 0.005$ \\
EPA1 & $5.7 \pm 0.2$ & $0.02 \pm 0.008$ \\
EPA2 & $6.9 \pm 0.2$ & $0.009 \pm 0.002$ \\
EPA3 & $6.5 \pm 0.2$ & $0.028 \pm 0.007$ \\
EPA4 & $6.8 \pm 0.1$ & $0.014 \pm 0.002$ \\
EPA5 & $6.0 \pm 0.1$ & $0.009 \pm 0.005$ \\
EPA6 & $5.8 \pm 0.1$ & $0.015 \pm 0.007$ \\
EPA7 & $6.4 \pm 0.2$ & $\mathrm{ND}$ \\
EPA8 & $5.6 \pm 0.3$ & $0.003 \pm 0.001$ \\
EPA9 & $7.4 \pm 0.1$ & $0.027 \pm 0.009$ \\
EPP1 & $6.5 \pm 0.2$ & $0.017 \pm 0.02$ \\
EPP2 & $6.9 \pm 0.1$ & $0.001 \pm 0.001$ \\
EPP3 & $6.3 \pm 0.2$ & $0.015 \pm 0.017$ \\
EPP4 & $6.1 \pm 0.1$ & $0.006 \pm 0.007$ \\
EPP5 & $6.1 \pm 0.3$ &
\end{tabular}

* WHO: World Health Organization, ND: not detected. 
$\mathrm{Pb}$ guideline of $0.01 \mathrm{mg} / \mathrm{L}$, water from spade-sunk wells EPA2, EPA4, EPA5 and EPA7 and from drilled wells EPP1 and EPP2 is the most contaminated by $\mathrm{Pb}$ for the period of February 2011. Pb concentrations of water from spade-sunk wells ranged from $0.012 \mathrm{mg} / \mathrm{L}$ to $0.031 \mathrm{mg} / \mathrm{L}$ with a mean of $0.02 \pm 0.008 \mathrm{mg} / \mathrm{L}$ for EPA2, from $0.02 \mathrm{mg} / \mathrm{L}$ to $0.039 \mathrm{mg} / \mathrm{L}$ with a mean of $0.028 \pm 0.007 \mathrm{mg} / \mathrm{L}$ for EPA4, from $0.01 \mathrm{mg} / \mathrm{L}$ to $0.017 \mathrm{mg} / \mathrm{L}$ with a mean of $0.014 \pm 0.003 \mathrm{mg} / \mathrm{L}$ for EPA5, and from $0.008 \mathrm{mg} / \mathrm{L}$ to $0.024 \mathrm{mg} / \mathrm{L}$ with a mean of $0.015 \pm 0.007 \mathrm{mg} / \mathrm{L}$ for EPA7, those of water from drilled wells varied from $0.01 \mathrm{mg} / \mathrm{L}$ to 0.033 $\mathrm{mg} / \mathrm{L}$ with a mean of $0.027 \pm 0.009 \mathrm{mg} / \mathrm{L}$ for EPP1 and from $0.001 \mathrm{mg} / \mathrm{L}$ to $0.05 \mathrm{mg} / \mathrm{L}$ with $0.017 \pm 0.02$ $\mathrm{mg} / \mathrm{L}$ mean concentration for EPP2.

$\mathrm{Pb}$ concentrations equal to or higher than the WHO [6] $0.01 \mathrm{mg} / \mathrm{L} \mathrm{Pb}$ guideline for drinking water were also periodically found in water from spade-sunk wells EPA1 $(0.017 \mathrm{mg} / \mathrm{L}$ in March), EPA3 $(0.01 \mathrm{mg} / \mathrm{L}$ in February and $0.011 \mathrm{mg} / \mathrm{L}$ in April), EPA6 (0.016 $\mathrm{mg} / \mathrm{L}$ in May and $0.012 \mathrm{mg} / \mathrm{L}$ in July), EPA7 $(0.02$ $\mathrm{mg} / \mathrm{L}$ in February, $0.024 \mathrm{mg} / \mathrm{L}$ in March, $0.019 \mathrm{mg} / \mathrm{L}$ in April and $0.01 \mathrm{mg} / \mathrm{L}$ in May) and in water from drilled wells EPP2 $(0.05 \mathrm{mg} / \mathrm{L}$ in February, $0.03 \mathrm{mg} / \mathrm{L}$ in March and $0.02 \mathrm{mg} / \mathrm{L}$ in April), EPP4 $(0.05 \mathrm{mg} / \mathrm{L}$ in February) and EPP5 (0.01 mg/L in February and $0.017 \mathrm{mg} / \mathrm{L}$ in March). More than 93\% (93.8\%) of analyzed water samples contained $\mathrm{Pb}$ and $44.8 \%$ of the samples had concentrations higher than the WHO [6] maximum permissible $\mathrm{Pb}$ concentration of 0.01 $\mathrm{mg} / \mathrm{L}$ in drinking water.

For the whole period of February to July 2011, the mean $\mathrm{Pb}$ levels and standard deviations of faucet water EDD2 $(0.014 \pm 0.019 \mathrm{mg} / \mathrm{L})$, spade-sunk well water EPA2 $(0.02 \pm 0.008 \mathrm{mg} / \mathrm{L})$, EPA4 $(0.028 \pm$ $0.007 \mathrm{mg} / \mathrm{L})$ and $\operatorname{EPA} 5(0.014 \pm 0.002 \mathrm{mg} / \mathrm{l})$ and drilled well water EPP1 $(0.027 \pm 0.009 \mathrm{mg} / \mathrm{L})$, EPP2 $(0.017 \pm 0.02 \mathrm{mg} / \mathrm{L})$ and EPP4 $(0.015 \pm 0.017 \mathrm{mg} / \mathrm{L})$ were higher than the WHO [6] $\mathrm{Pb}$ guideline of 0.01 $\mathrm{mg} / \mathrm{L}$ for drinking water (Table 2).

The high $\mathrm{Pb}$ concentrations of water from different spade sunk-wells and drilled wells and, from one water supply faucet may result from a surface contamination by tailings and also from interaction between groundwater and underground minerals contained in geological formations.

$\mathrm{Pb}$ concentrations higher than the WHO [6] 0.01 $\mathrm{mg} / \mathrm{L} \mathrm{Pb}$ guideline for drinking water present a risk to the public health due to the high toxicity of that metal. $\mathrm{Pb}$ has been recognized since decades to be a general and cumulative metabolic poison [7]. Children are particularly sensitive to $\mathrm{Pb}$ exposure due to high gastro-intestinal absorption and permeable blood-brain barrier [8]. Martin and Griswold [9] reported that $\mathrm{Pb}$ is a probable carcinogen for man and that long term exposure to $\mathrm{Pb}$ may result in reduced performance to some tests that measure the functions of the nervous system, weakness of fingers, wrists or ankles, light increase of blood pressure and anemia.

According to Martin, S., and Griswold, W. [9], exposure to high $\mathrm{Pb}$ levels may cause severe damage to brain, kidneys and ultimate death. Exposure to high $\mathrm{Pb}$ levels may cause abortion to pregnant women and may damage the organs responsible for sperm production in men. Other studies have linked $\mathrm{Pb}$ exposure, even at low concentrations, to an increase of arterial pressure as well as a weak intelligence quotient in children and a disorder in attention [10-12]. Also Glover-Kerkvliet [13] reported that exposure high $\mathrm{Hg}$, $\mathrm{Au}$ and $\mathrm{Pb}$ concentrations is associated with auto-immunity development that drives the immunity system to attack its own cells, mistaking them for invaders. According to the author, auto-immunity may lead to the development of kidney and articulation diseases, such as rheumatoid arthritis, and circulatory system and central nervous system diseases.

Exposure to high $\mathrm{Pb}$ levels may result in toxic biochemical effects in human beings, effects which in return cause problems of hemoglobin synthesis, negative effects on kidneys, digestive tube, articulations and reproductive system and acute or chronic damage to the nervous system [14]. The same 
source indicates that at intermediate $\mathrm{Pb}$ levels, there is a persuasive evidence that $\mathrm{Pb}$ may have small subtle sub-clinical effects, particularly on the neuropsychological developments in children, and certain other studies suggest that there may be loss of Intelligence Quotient (IQ) till 2 IQ points for an increase of $\mathrm{Pb}$ levels of 10-20 micrograms per deciliter $(\mu \mathrm{g} / \mathrm{dL})$ in young children.

\subsubsection{Aluminium $(\mathrm{Al})$}

All analyzed water samples had detectable Al concentrations except samples collected from the drilled well EPP2. About $78 \%$ of water samples from spade-sunk wells (seven over nine wells) periodically had $\mathrm{Al}$ concentrations higher than the $0.2 \mathrm{mg} / \mathrm{L}$ WHO [6] maximum permissible Al concentration limit in drinking water. Very high $\mathrm{Al}$ concentrations greater than the WHO maximum permissible $\mathrm{Al}$ concentration limit of $0.2 \mathrm{mg} / \mathrm{L}$ in drinking water were noted in water from spade-sunk wells EPA1 in February $(1 \mathrm{mg} / \mathrm{L})$, EPA2 in February and March $(1.84 \mathrm{mg} / \mathrm{L}$ and $0.92 \mathrm{mg} / \mathrm{L}$, respectively), EPA3 in February $(0.22 \mathrm{mg} / \mathrm{L})$, EPA6 in February and March $(0.46 \mathrm{mg} / \mathrm{L}$ and $0.35 \mathrm{mg} / \mathrm{L}$, respectively), EPA7 in February $(0.34 \mathrm{mg} / \mathrm{L})$ and EPA8 in February and March ( $4.31 \mathrm{mg} / \mathrm{L}$ and $2.05 \mathrm{mg} / \mathrm{L}$, respectively). From February to July 2011, mean Al concentrations of water from spade-sunk wells EPA1 $(0.228 \pm 0.381$ $\mathrm{mg} / \mathrm{L})$, EPA2 $(0.539 \pm 0.713 \mathrm{mg} / \mathrm{L})$, EPA6 $(0.241 \pm$ $0.132 \mathrm{mg} / \mathrm{L})$ and EPA8 $(1.106 \pm 1.758 \mathrm{mg} / \mathrm{L})$ were higher than the $0.2 \mathrm{mg} / \mathrm{L}$ WHO [6] maximum permissible $\mathrm{Al}$ concentration limit in drinking water (Table 3 and Fig. 3). These results indicated that water from spade sunk wells, which is a shallow groundwater of 2-15 meter deep, was highly contaminated by $\mathrm{Al}$.

$\mathrm{Al}$ is absorbed through the digestive tract or the lungs and can reach other body tissues. Neurological diseases such as the Alzheimer's disease, the Parkinson's disease and many others are presently being studied with connection to excess $\mathrm{Al}$ in the brain tissues [15].
Table 3 Mean values and standard deviations of $\mathbf{p H}$ and Al levels of supply water and well water in Kipushi in 2011, and the WHO [6] guidelines.

\begin{tabular}{lll}
\hline & \multicolumn{2}{l}{$\begin{array}{l}\text { WHO* drinking water } \mathrm{pH} \text { optimum and } \\
\text { maximum permissible Al concentration } \\
\text { limit, and Al mean concentration values } \\
\text { with standard deviation of the water samples }\end{array}$} \\
\cline { 2 - 3 } & $\mathrm{p}$ Al $(\mathrm{mg} / \mathrm{L})$ \\
\hline WHO* & $6.5-9.5$ & 0.2 \\
guidelines & & \\
water sample & & $0.012 \pm 0.007$ \\
EDD1 & $7.4 \pm 0.1$ & $0.003 \pm 0.004$ \\
EDD2 & $7.2 \pm 0.1$ & $0.228 \pm 0.381$ \\
EPA1 & $5.7 \pm 0.2$ & $0.539 \pm 0.713$ \\
EPA2 & $6.9 \pm 0.2$ & $0.176 \pm 0.025$ \\
EPA3 & $6.5 \pm 0.2$ & $0.153 \pm 0.036$ \\
EPA4 & $6.8 \pm 0.1$ & $0.038 \pm 0.032$ \\
EPA5 & $6.0 \pm 0.1$ & $0.241 \pm 0.132$ \\
EPA6 & $5.8 \pm 0.1$ & $0.117 \pm 0.121$ \\
EPA7 & $6.4 \pm 0.2$ & $1.106 \pm 1.758$ \\
EPA8 & $5.6 \pm 0.3$ & $0.059 \pm 0.019$ \\
EPA9 & $7.4 \pm 0.1$ & $0.021 \pm 0.019$ \\
EPP1 & $6.5 \pm 0.2$ & $\mathrm{ND}$ \\
EPP2 & $6.9 \pm 0.1$ & $0.012 \pm 0.01$ \\
EPP3 & $6.3 \pm 0.2$ & $0.004 \pm 0.004$ \\
EPP4 & $6.1 \pm 0.1$ & $0.018 \pm 0.01$ \\
EPP5 & $6.1 \pm 0.3$ &
\end{tabular}

* WHO: World Health Organization, ND: not detected.

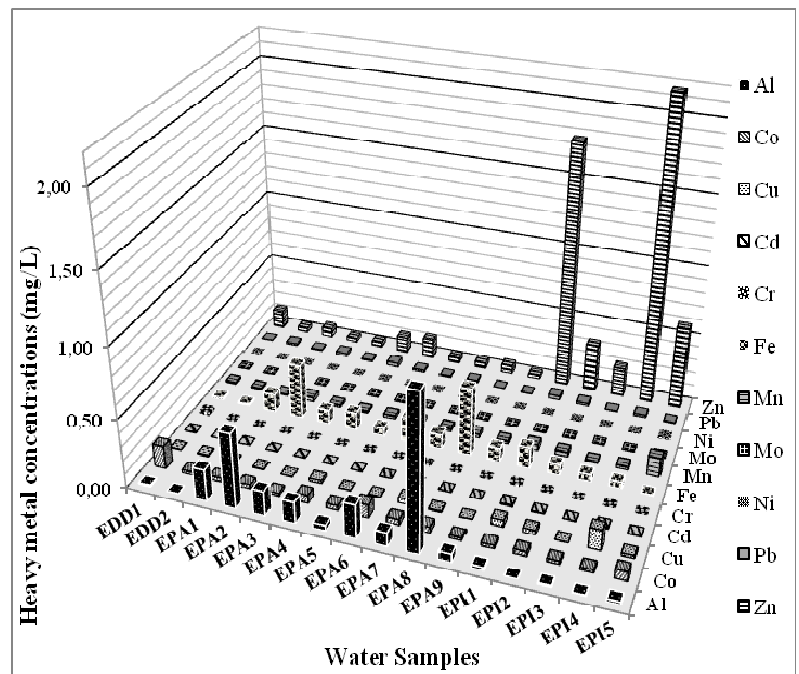

Fig. 3 Mean concentrations of various heavy metals in supply water and well water $(\mathrm{mg} / \mathrm{L})$ in the Kipushi mining town in 2011.

$\mathrm{Al}$ and $\mathrm{Hg}$ would be implicated in the Alzheimer's disease etiology as well as in certain forms of cancer such as lymphomas and reticulo-sarcomas [16]. 
According to the same source, the oxidative alteration by the metals ( $\mathrm{Al}, \mathrm{Fe}, \mathrm{Zn}$ and $\mathrm{Cu}$ ), their deregulation and their accumulation in the cerebral tissue cause the formation of free radicals.

\subsubsection{Cadmium $(\mathrm{Cd})$}

Over the five drilled wells, four (EPP1, EPP2, EPP4 and EPP5) had water with $\mathrm{Cd}$ concentration periodically higher than the $0.003 \mathrm{mg} / \mathrm{L}$ WHO [6] maximum permissible $\mathrm{Cd}$ concentration limit in drinking water. $\mathrm{Cd}$ concentrations varied from 0.001 $\mathrm{mg} / \mathrm{L}$ to $0.04 \mathrm{mg} / \mathrm{L}$ with a mean of $0.011 \pm 0.015$ $\mathrm{mg} / \mathrm{L}$ in the drilled well water EPP1, from 0.001-0.01 $\mathrm{mg} / \mathrm{L}$ with a mean of $0.003 \pm 0.004 \mathrm{mg} / \mathrm{L}$ in the EPP2 water, from $0-0.03 \mathrm{mg} / \mathrm{L}$ with a mean of $0.008 \pm 0.011$ $\mathrm{mg} / \mathrm{L}$ in the EPP4 water, and from $0-0.01 \mathrm{mg} / \mathrm{L}$ with a mean concentration of $0.003 \pm 0.004 \mathrm{mg} / \mathrm{L}$ in the EPP5 water (Table 4).

$\mathrm{Cd}$ was not detected in samples of faucet water EDD1 and in water samples from the spade-sunk wells EPA1, EPA2, EPA5, EPA6 and EPA9 and from the drilled well EPP3. Cd concentrations found in the other water samples ranged from $0-0.001 \mathrm{mg} / \mathrm{L}$ in faucet water EDD2, from $0-0.003 \mathrm{mg} / \mathrm{L}$ in water from the spade-sunk wells EPA3, EPA4, EPA7 and EPA8, and from $0-0.04 \mathrm{mg} / \mathrm{L}$ in water from the very deep wells EPP1, EPP2, EPP4 and EPP5. Over the five drilled wells, four (EPP1, EPP2, EPP4 and EPP5) had water with $\mathrm{Cd}$ concentration periodically higher than the $0.003 \mathrm{mg} / \mathrm{L}$ WHO [6] maximum permissible $\mathrm{Cd}$ concentration limit in drinking water. $\mathrm{Cd}$ concentrations varied from $0.001-0.04 \mathrm{mg} / \mathrm{L}$ with a mean of $0.011 \pm 0.015 \mathrm{mg} / \mathrm{L}$ in the EPP1 drilled well water, from $0.001-0.01 \mathrm{mg} / \mathrm{L}$ with a mean of $0.003 \pm$ $0.004 \mathrm{mg} / \mathrm{L}$ in the EPP2 well water, from $0-0.03 \mathrm{mg} / \mathrm{L}$ with a mean of $0.008 \pm 0.011 \mathrm{mg} / \mathrm{L}$ in the EPP4 well water, and from $0-0.01 \mathrm{mg} / \mathrm{L}$ with a mean concentration of $0.003 \pm 0.004 \mathrm{mg} / \mathrm{L}$ in the EPP5 well water.

The Cd found in water from spade-sunk wells and drilled wells of 30-60 meter depth probably came from the host rock which contains different metals of
Table 4 Mean values and standard deviations of $\mathbf{p H}$ and Cd levels of supply water and well water in Kipushi in 2011, and the WHO [6] guidelines.

\begin{tabular}{ll} 
WHO* drinking water $\mathrm{pH}$ optimum and \\
maximum permissible Cd concentration \\
limit, and Cd mean concentration values \\
with standard deviation of the water samples \\
\hline $\mathrm{pH}$ & $\mathrm{Cd}(\mathrm{mg} / \mathrm{L})$ \\
$6.5-9.5$ & 0.003 \\
& \\
$7.4 \pm 0.1$ & $\mathrm{ND}$ \\
$7.2 \pm 0.1$ & $0.001 \pm 0.001$ \\
$5.7 \pm 0.2$ & $\mathrm{ND}$ \\
$6.9 \pm 0.2$ & $\mathrm{ND}$ \\
$6.5 \pm 0.2$ & $0.001 \pm 0.001$ \\
$6.8 \pm 0.1$ & $0.001 \pm 0.001$ \\
$6.0 \pm 0.1$ & $\mathrm{ND}$ \\
$5.8 \pm 0.1$ & $\mathrm{ND}$ \\
$6.4 \pm 0.2$ & $0.001 \pm 0.001$ \\
$5.6 \pm 0.3$ & $\mathrm{ND}$ \\
$7.4 \pm 0.1$ & $\mathrm{ND}$ \\
$6.5 \pm 0.2$ & $0.009 \pm 0.015$ \\
$6.9 \pm 0.1$ & $0.003 \pm 0.004$ \\
$6.3 \pm 0.2$ & $\mathrm{ND}$ \\
$6.1 \pm 0.1$ & $0.008 \pm 0.011$ \\
$6.1 \pm 0.3$ & $0.003 \pm 0.004$ \\
6 &
\end{tabular}

* WHO: World Health Organization, ND: not detected.

which $\mathrm{Cd}$, but also from the releasing and the migration of that metal from the Kipushi tailings to the groundwater table. Cd concentrations similar to those found in water from four drilled wells (EPP1, EPP2, EPP4 and EPP5) in the Kipushi mining town were noted by Iqbal and Gupta [17] in groundwater sources in Naregaon (India), by Makkasap and Satapanajaru [18] in groundwater in the Rayong province (Thailand), and by Akoteyon et al. [19] in groundwater in Alimosho, Lagos (Nigeria).

Knowing that $\mathrm{Cd}$ is a very toxic metal and that concentrations of that metal in drinking water are generally low, lower than $0.001 \mathrm{mg} / \mathrm{L}$ [20], the high Cd levels of water from the very deep drilled wells EPP1, EPP2, EPP4 and EPP5 in the Kipushi mining town constitute a serious health risk for the people who consume that water. $\mathrm{Cd}$ and $\mathrm{Cd}$ compounds are 
known to be carcinogenic and ingestion of very high $\mathrm{Cd}$ concentrations severely irritates the stomach, leading to vomiting and diarrhea when in fact long-term exposure to low $\mathrm{Cd}$ concentrations carries to the accumulation of that metal in the kidneys and possible kidney disease, damage of lungs, and weakening of bones [9]. Other studies indicate that the negative effects on health may occur due to exposure to $\mathrm{Cd}$ at concentrations lower than those previously expected, mainly in the form of damage to kidneys but also possibly effects on bones and the fracture of the latter [8, 21-23]. The highest Cd concentration (0.04 $\mathrm{mg} / \mathrm{L}$ ) was found in water from the drilled well EPP1 in February and the same water had the highest mean Cd concentration $(0.009 \mathrm{mg} / \mathrm{L})$ for the period of February to July 2011.

$\mathrm{Cd}$ causes renal, lung and bone injuries and prostate cancer. $\mathrm{Cd}$ concentrated in the body also causes high blood pressure, liver disease and problems in the nervous system. The kidneys normally evacuate toxins in urine produced by the former. But $\mathrm{Cd}$ accumulates in the kidneys where it damages the filtration mechanisms. That causes the excretion of essential proteins and sugar from the organism. It takes a lot of time for the $\mathrm{Cd}$ that has been accumulated to get excreted from the body. The other problems created by $\mathrm{Cd}$ are: diarrhea, stomach pains and important vomiting, bone fracture, sterility, central nervous system problems, psychological disorder, problems at the immune system level, alteration of the deoxyribonucleic acid (DNA) and cancer development $[16,24,25]$. In human beings, long-term exposure to $\mathrm{Cd}$ is associated to renal dysfunction. High $\mathrm{Cd}$ exposure may lead to lung obstructive disease and is even linked to lung cancer [14]. According to the same source, Cd may also cause bone diseases (osteomalacia, osteoporosis) in human beings and animals and, besides, that metal may be linked to high blood pressure and negative effects on the myocardium in animals. The same source indicates that in human beings the mean daily $\mathrm{Cd}$ intake is estimated to $0.15 \mu \mathrm{g}$ from the air and $1 \mu \mathrm{g}$ from water and that smoking a pack of 20 cigarettes may lead to the inhalation of about 2-4 $\mu \mathrm{g} \mathrm{Cd}$, but Cd levels may vary a lot.

\subsubsection{Cobalt ( $\mathrm{Co})$}

Co concentrations ranged from $0.003-0.18 \mathrm{mg} / \mathrm{L}$ in faucet water, from $0-0.16 \mathrm{mg} / \mathrm{L}$ in water from spade-sunk wells and from $0-0.15 \mathrm{mg} / \mathrm{L}$ in water from drilled wells (Table 5). Faucet water EDD1 had the highest Co concentration $(0.18 \mathrm{mg} / \mathrm{L})$ in March and the highest mean concentration $(0.162 \pm 0.013 \mathrm{mg} / \mathrm{L}$ for the period of February to July 2011. No guideline for Co in drinking water has been determined by WHO [6].

Studies carried out in the United States of America have shown that Co concentration in surface water and groundwater in that country is generally low, between $1-10 \mathrm{ppb}$ in densely populated zones but the concentration may be hundred or thousand times higher in zones rich in minerals containing Co or in zones near mining extraction operations or smelting [26]. According to the same source, Co concentrations normally found in the environment are not sufficiently higher to result in excessive Co concentrations in food or water. Co has beneficial effects and harmful effects on human health.

Co is beneficial to human beings because it enters in the composition of vitamin B12 which is essential to maintain human health. Co $(0.16-1 \mathrm{mg} / \mathrm{kg}$ Co of body weight) is also used in anemia treatment including pregnant women because it causes red blood corpuscle production. Also Co is essential for the health of various animals, such as cattle and sheep. Exposure of human beings and animals to Co levels normally found in the environment is not harmful. However, when one is exposed to high Co levels by ingestion, by respiration or by contact, the harmful effects to health may occur [25].

Chronic exposure of human beings to Co by inhalation results in effects on the respiratory system, such as respiratory irritation, noisy or wheezing respiration, asthma, pneumonia, reduced pulmonary 
Table 5 Mean values and standard deviations of $\mathbf{p H}$ and Co levels of supply water and well water in Kipushi in 2011, and the WHO [6] guidelines.

$\mathrm{WHO}^{*}$ drinking water $\mathrm{pH}$ optimum, and $\mathrm{Co}$ mean concentration values with standard deviation of the samples

\begin{tabular}{lll} 
& $\mathrm{pH}$ & $\mathrm{Co}(\mathrm{mg} / \mathrm{L})$ \\
\hline $\begin{array}{l}\text { WHO* } \\
\text { guidelines }\end{array}$ & $6.5-9.5$ & - \\
water sample & & \\
EDD1 & $7.4 \pm 0.1$ & $0.162 \pm 0.013$ \\
EDD2 & $7.2 \pm 0.1$ & $0.021 \pm 0.018$ \\
EPA1 & $5.7 \pm 0.2$ & $0.029 \pm 0.021$ \\
EPA2 & $6.9 \pm 0.2$ & $0.028 \pm 0.042$ \\
EPA3 & $6.5 \pm 0.2$ & $0.018 \pm 0.018$ \\
EPA4 & $6.8 \pm 0.1$ & $0.055 \pm 0.07$ \\
EPA5 & $6.0 \pm 0.1$ & $0.033 \pm 0.033$ \\
EPA6 & $5.8 \pm 0.1$ & $0.094 \pm 0.055$ \\
EPA7 & $6.4 \pm 0.2$ & $0.04 \pm 0.041$ \\
EPA8 & $5.6 \pm 0.3$ & $0.041 \pm 0.058$ \\
EPA9 & $7.4 \pm 0.1$ & $0.019 \pm 0.026$ \\
EPP1 & $6.5 \pm 0.2$ & $0.022 \pm 0.015$ \\
EPP2 & $6.9 \pm 0.1$ & $0.033 \pm 0.023$ \\
EPP3 & $6.3 \pm 0.2$ & $0.023 \pm 0.043$ \\
EPP4 & $6.1 \pm 0.1$ & $0.019 \pm 0.031$ \\
EPP5 & $6.1 \pm 0.3$ & $0.064 \pm 0.063$ \\
\hline
\end{tabular}

* WHO: World Health Organization.

function, and fibrosis [25, 26]. Other Co effects due to Co exposure by inhalation include cardiac effects, such as functional effects on ventricles and heart enlargement, congestion of liver, kidneys and conjunctivitis, and immunological effects which include sensitivity to Co that can speed asthmatic attack in sensitive individuals [25, 27]. Gastrointestinal effects (nausea, vomiting and diarrhea), effects on blood, liver, wounds and allergic dermatitis have been reported in human beings due to Co exposure by ingestion [25].

\subsubsection{Chromium $(\mathrm{Cr})$}

$\mathrm{Cr}$ analyzed in water is total $\mathrm{Cr}$ which includes $\mathrm{Cr}(\mathrm{III})$ and $\mathrm{Cr}(\mathrm{VI})$. The U.S. Environmental Protection Agency (EPA) regulation assumes that the measure of total $\mathrm{Cr}$ is $100 \% \mathrm{Cr}(\mathrm{VI})$ - the most toxic form [28]. $\mathrm{Cr}$ was not detected in most water samples from spade-sunk wells and drilled wells EPP2 and EPP5. Cr levels of faucet water $(0-0.03 \mathrm{mg} / \mathrm{L})$, those of water from spade-sunk wells $(0-0.001 \mathrm{mg} / \mathrm{L})$ and from drilled wells $(0-0.04 \mathrm{mg} / \mathrm{L})$ were lower than the $0.05 \mathrm{mg} / \mathrm{L}$ WHO [6] maximum permissible $\mathrm{Cr}$ concentration limit in drinking water (Table 6).

Those $\mathrm{Cr}$ levels were similar to those noted by Iqbal and Gupta [17] in groundwater sources near a solid waste municipal discharge in Naregon, India. $\mathrm{Cr}$ concentrations found in faucet water and in well water in the Kipushi mining town were lower than those of $\mathrm{Cr}(\mathrm{VI})$ found in faucet water in 25 of the 31 large cities of the United States of America in 2010. The $\mathrm{Cr}(\mathrm{VI})$ concentrations found in faucet water of the 25 American cities were lower than the $0.1 \mathrm{mg} / \mathrm{L}$ guideline established by the U.S. EPA for all combined forms of $\mathrm{Cr}$ in drinking water [29].

Table 6 Mean values and standard deviations of $\mathrm{pH}$ and Cr levels of supply water and well water in Kipushi in 2011, and the WHO [6] guidelines.

\begin{tabular}{lll}
\hline & \multicolumn{2}{l}{$\begin{array}{l}\text { WHO* drinking water } \mathrm{pH} \text { optimum and } \\
\text { maximum permissible } \mathrm{Cr} \text { concentration } \\
\text { limit, and Cr mean concentration values } \\
\text { with standard deviation of the water samples }\end{array}$} \\
\cline { 2 - 3 } & $\mathrm{pH}$ & $\mathrm{Cr}(\mathrm{mg} / \mathrm{L})$ \\
\hline WHO* & $6.5-9.5$ & 0.05 \\
guidelines & & \\
water sample & & $0.024 \pm 0.005$ \\
EDD1 & $7.4 \pm 0.1$ & $0.0002 \pm 0.0004$ \\
EDD2 & $7.2 \pm 0.1$ & $\mathrm{ND}$ \\
EPA1 & $5.7 \pm 0.2$ & $\mathrm{ND}$ \\
EPA2 & $6.9 \pm 0.2$ & $\mathrm{ND}$ \\
EPA3 & $6.5 \pm 0.2$ & $\mathrm{ND}$ \\
EPA4 & $6.8 \pm 0.1$ & $\mathrm{ND}$ \\
EPA5 & $6.0 \pm 0.1$ & $\mathrm{ND}$ \\
EPA6 & $5.8 \pm 0.1$ & $0.001 \pm 0.001$ \\
EPA7 & $6.4 \pm 0.2$ & $0.001 \pm 0.001$ \\
EPA8 & $5.6 \pm 0.3$ & $\mathrm{ND}$ \\
EPA9 & $7.4 \pm 0.1$ & $0.008 \pm 0.016$ \\
EPP1 & $6.5 \pm 0.2$ & $\mathrm{ND}$ \\
EPP2 & $6.9 \pm 0.1$ & $0.001 \pm 0.001$ \\
EPP3 & $6.3 \pm 0.2$ & $0.005 \pm 0.006$ \\
EPP4 & $6.1 \pm 0.1$ & $\mathrm{ND}$ \\
EPP5 & $6.1 \pm 0.3$ &
\end{tabular}

* WHO: World Health Organization, ND: not detected. 
$\mathrm{Cr}(\mathrm{VI})$ compounds are toxins and they are known to be carcinogenic for man. Whereas, $\mathrm{Cr}$ (III) is an essential nutrient and long-term exposure to $\mathrm{Cr}$ may cause damage to the liver and kidney circulatory and nervous tissues, as well as skin irritation [9].

According to Martin, S., and Griswold, W. [9], breathing high $\mathrm{Cr}$ levels may cause nose mucus irritation, nose ulcers, cold and breathing problems such as asthma, cough, short respiration or wheezing respiration, and that skin contact with $\mathrm{Cr}$ may cause skin ulcers. Furthermore, they reported that allergic reactions consisting in severe redness and skin swelling have been noted, and that long-term exposure to $\mathrm{Cr}$ may cause damages to liver, circulatory and nervous tissues of the kidneys, as well as skin irritation. Exposure to low Cr levels may irritate the skin and cause ulceration, whereas, long-term exposure may damage the kidneys and the liver, and also damage the tissue of the circulatory system and nerves [14].

\subsubsection{Copper $(\mathrm{Cu})$}

$\mathrm{Cu}$ levels ranged from $0.001-0.019 \mathrm{mg} / \mathrm{L}$ with a mean of $0.007 \mathrm{mg} / \mathrm{L}$ in faucet water, from $0-0.077$ $\mathrm{mg} / \mathrm{L}$ with a mean of $0.01 \mathrm{mg} / \mathrm{L}$ in water from spade-sunk wells, and from $0-0.39 \mathrm{mg} / \mathrm{L}$ with a mean of $0.048 \mathrm{mg} / \mathrm{L}$ in water from drilled wells, but they were lower than the $2 \mathrm{mg} / \mathrm{L}$ WHO [6] maximum permissible $\mathrm{Cu}$ concentration limit in drinking water (Table 7).

$\mathrm{Cu}$ was not detected in water samples from the drilled well EPP3. The highest $\mathrm{Cu}$ concentration (0.39 $\mathrm{mg} / \mathrm{L}$ ) was found in water from the drilled well EPP4 in February and that water had the highest mean $\mathrm{Cu}$ concentration $(0.143 \mathrm{mg} / \mathrm{L})$ for the period of February to July 2011.

The low $\mathrm{Cu}$ concentrations found in the Kipushi well water suggested that those wells were less contaminated by that metal of which mobility is lower than that of $\mathrm{As}, \mathrm{Cd}, \mathrm{Pb}$ and $\mathrm{Zn}[4,5]$.

$\mathrm{Cu}$ is an essential element present in all tissues and it is necessary for cellular respiration, peptide amidation, neurotransmitter biosynthesis, pigment formation and
Table 7 Mean values and standard deviations of $\mathbf{p H}$ and $\mathrm{Cu}$ levels of supply water and well water in Kipushi in 2011, and the WHO [6] guidelines.

\begin{tabular}{lll} 
& \multicolumn{2}{l}{$\begin{array}{l}\text { WHO* drinking water } \mathrm{pH} \text { optimum and } \\
\text { maximum permissible } \mathrm{Cu} \text { concentration } \\
\text { limit, and } \mathrm{Cu} \text { mean concentration values } \\
\text { with standard deviation of the water samples }\end{array}$} \\
\cline { 2 - 3 } & $\mathrm{pH}$ & \multicolumn{1}{c}{$\mathrm{Cu}(\mathrm{mg} / \mathrm{L})$} \\
\hline WHO* & $6.5-9.5$ & 2 \\
guidelines & & \\
water sample & & $0.004 \pm 0.003$ \\
EDD1 & $7.4 \pm 0.1$ & $0.009 \pm 0.006$ \\
EDD2 & $7.2 \pm 0.1$ & $0.007 \pm 0.006$ \\
EPA1 & $5.7 \pm 0.2$ & $0.006 \pm 0.007$ \\
EPA2 & $6.9 \pm 0.2$ & $0.001 \pm 0.001$ \\
EPA3 & $6.5 \pm 0.2$ & $0.022 \pm 0.024$ \\
EPA4 & $6.8 \pm 0.1$ & $0.001 \pm 0.0004$ \\
EPA5 & $6.0 \pm 0.1$ & $0.006 \pm 0.007$ \\
EPA6 & $5.8 \pm 0.1$ & $0.036 \pm 0.038$ \\
EPA7 & $6.4 \pm 0.2$ & $0.008 \pm 0.007$ \\
EPA8 & $5.6 \pm 0.3$ & $0.002 \pm 0.001$ \\
EPA9 & $7.4 \pm 0.1$ & $0.048 \pm 0.045$ \\
EPP1 & $6.5 \pm 0.2$ & $0.029 \pm 0.007$ \\
EPP2 & $6.9 \pm 0.1$ & $\mathrm{ND}$ \\
EPP3 & $6.3 \pm 0.2$ & $0.143 \pm 0.147$ \\
EPP4 & $6.1 \pm 0.1$ & $0.020 \pm 0.024$ \\
EPP5 & $6.1 \pm 0.3$ & \\
\hline
\end{tabular}

* WHO: World Health Organization, ND: not detected.

connective tissue strength. It is a cofactor for numerous enzymes and it plays an important role in the development of the central nervous system [30] but, in high concentrations it can cause anemia, liver and kidney damages, and stomach and intestine irritation [14]. $\mathrm{Cu}$ is present in the brain and it is the most notable in the essential ganglions, hippocampus, cerebellum, numerous synaptic membranes and in the cell bodies of cortical pyramidal and granular neurons of the cerebellum $[30,31]$. $\mathrm{Cu}$ is directly or indirectly implicated in the pathogenesis of many neurological diseases, especially aceruloplasminemia, Alzheimer's disease, lateral amyotrophic sclerosis, Huntington's disease, prion disease and Wilson's disease [30].

\subsubsection{Iron (Fe)}

Fe concentrations ranged from $0.009-0.017 \mathrm{mg} / \mathrm{L}$ with a mean of $0.013 \mathrm{mg} / \mathrm{L}$ in faucet water, from 
$0.003-1.83 \mathrm{mg} / \mathrm{L}$ with a mean of $0.181 \mathrm{mg} / \mathrm{L}$ in water from spade-sunk wells and from $0.001-0.31 \mathrm{mg} / \mathrm{L}$ with a mean of $0.065 \mathrm{mg} / \mathrm{L}$ in water from drilled wells (Table 8).

The spade-sunk wells EPA1, EPA2 and EPA8 and the drilled well EPP1 had water which periodically presented Fe concentrations higher than the $0.3 \mathrm{mg} / \mathrm{L}$ WHO [6] Fe guideline for drinking water. Water from the spade-sunk well EPA8 had the highest Fe concentration $(1.83 \mathrm{mg} / \mathrm{L})$ in February and the highest Fe mean concentration $(0.491 \mathrm{mg} / \mathrm{L})$. That water also had the lowest $\mathrm{pH}$ value (pH 5.2) in February and the lowest mean $\mathrm{pH}$ value $(5.6 \pm 0.3)$ for the period of February to July.

It is known that $\mathrm{pH}$ plays an important role in the mobility of metals. An acidic $\mathrm{pH}$ causes the putting in solution of metallic salts, the putting in solution of

Table 8 Mean values and standard deviations of $\mathrm{pH}$ and Fe levels of supply water and well water in Kipushi in 2011, and the WHO [6] guidelines.

\begin{tabular}{lll}
\hline & \multicolumn{2}{l}{ WHO* drinking water $\mathrm{pH}$ optimum and } \\
& $\begin{array}{l}\text { maximum permissible Fe concentration } \\
\text { limit, and Fe mean concentration values }\end{array}$ \\
& with standard deviation of the water samples \\
\cline { 2 - 3 } & $\mathrm{pH}$ & \multicolumn{1}{c}{$\mathrm{Fe}(\mathrm{mg} / \mathrm{L})$} \\
\hline WHO* $^{*}$ & $6.5-9.5$ & 0.3 \\
guidelines & & \\
water sample & & $0.014 \pm 0.002$ \\
EDD1 & $7.4 \pm 0.1$ & $0.012 \pm 0.002$ \\
EDD2 & $7.2 \pm 0.1$ & $0.131 \pm 0.211$ \\
EPA1 & $5.7 \pm 0.2$ & $0.396 \pm 0.458$ \\
EPA2 & $6.9 \pm 0.2$ & $0.1 \pm 0.029$ \\
EPA3 & $6.5 \pm 0.2$ & $0.125 \pm 0.095$ \\
EPA4 & $6.8 \pm 0.1$ & $0.057 \pm 0.062$ \\
EPA5 & $6.0 \pm 0.1$ & $0.175 \pm 0.057$ \\
EPA6 & $5.8 \pm 0.1$ & $0.074 \pm 0.063$ \\
EPA7 & $6.4 \pm 0.2$ & $0.491 \pm 0.735$ \\
EPA8 & $5.6 \pm 0.3$ & $0.098 \pm 0.014$ \\
EPA9 & $7.4 \pm 0.1$ & $0.152 \pm 0.127$ \\
EPP1 & $6.5 \pm 0.2$ & $0.074 \pm 0.023$ \\
EPP2 & $6.9 \pm 0.1$ & $0.052 \pm 0.019$ \\
EPP3 & $6.3 \pm 0.2$ & $0.047 \pm 0.051$ \\
EPP4 & $6.1 \pm 0.1$ & $0.003 \pm 0.001$ \\
EPP5 & $6.1 \pm 0.3$ & \\
\hline
\end{tabular}

* WHO: World Health Organization. retention phases, desorption of cations and adsorption of anions [32]. Thus, solubility decreases when $\mathrm{pH}$ increases, reaches the minimum, then it increases when the element gets back to anionic form. Certain metals are more or less mobile according to their oxidation-reduction status. For instance, $\mathrm{Cr}$ is considered as toxic and mobile under the $\mathrm{Cr}(\mathrm{VI})$ form but not under its $\mathrm{Cr}$ (III) form. It has been noted that oxidative alteration by metals such as $\mathrm{Al}, \mathrm{Fe}, \mathrm{Zn}$ and $\mathrm{Cu}$, their deregulation and their accumulation in the brain tissue cause the formation of free radicals [16].

\subsubsection{Manganese (Mn)}

Mn concentrations ranged from $0.001-0.031 \mathrm{mg} / \mathrm{L}$ with a mean of $0.013 \mathrm{mg} / \mathrm{L}$ in faucet water, from $0.001-0.052 \mathrm{mg} / \mathrm{L}$ with a mean of $0.021 \mathrm{mg} / \mathrm{L}$ in spade-sunk well water, and from $0.002-0.19 \mathrm{mg} / \mathrm{L}$ with a mean of $0.027 \mathrm{mg} / \mathrm{L}$ in drilled well water (Table 9).

Table 9 Mean values and standard deviations of $\mathrm{pH}$ and Mn levels of supply water and well water in Kipushi in 2011, and the WHO [6] guidelines.

\begin{tabular}{lll}
\hline & \multicolumn{2}{l}{$\begin{array}{l}\text { WHO* drinking water pH optimum and } \\
\text { maximum permissible Mnconcentration } \\
\text { limit, and Mn mean concentration values } \\
\text { with standard deviation of the water samples }\end{array}$} \\
\cline { 2 - 3 } & pH & \multicolumn{1}{c}{ Mn $(\mathrm{mg} / \mathrm{L})$} \\
\hline WHO* & $6.5-9.5$ & 0.4 \\
guidelines & & \\
water sample & & $0.014 \pm 0.005$ \\
EDD1 & $7.4 \pm 0.1$ & $0.011 \pm 0.011$ \\
EDD2 & $7.2 \pm 0.1$ & $0.01 \pm 0.001$ \\
EPA1 & $5.7 \pm 0.2$ & $0.031 \pm 0.02$ \\
EPA2 & $6.9 \pm 0.2$ & $0.017 \pm 0.002$ \\
EPA3 & $6.5 \pm 0.2$ & $0.014 \pm 0.009$ \\
EPA4 & $6.8 \pm 0.1$ & $0.022 \pm 0.004$ \\
EPA5 & $6.0 \pm 0.1$ & $0.025 \pm 0004$ \\
EPA6 & $5.8 \pm 0.1$ & $0.02 \pm 0.005$ \\
EPA7 & $6.4 \pm 0.2$ & $0.025 \pm 0.008$ \\
EPA8 & $5.6 \pm 0.3$ & $0.021 \pm 0006$ \\
EPA9 & $7.4 \pm 0.1$ & $0.04 \pm 0.02$ \\
EPP1 & $6.5 \pm 0.2$ & $0.033 \pm 0023$ \\
EPP2 & $6.9 \pm 0.1$ & $0.01 \pm 0.006$ \\
EPP3 & $6.3 \pm 0.2$ & $0.022 \pm 0.007$ \\
EPP4 & $6.1 \pm 0.1$ & $0.135 \pm 0.068$ \\
EPP5 & $6.1 \pm 0.3$ & \\
\hline
\end{tabular}

* WHO: World Health Organization. 
All those water Mn levels were lower than the 0.4 $\mathrm{mg} / \mathrm{L}$ WHO [6] maximum permissible Mn concentration limit in drinking water. Water from the drilled well EPP5 had the highest Mn concentration $(0.19 \mathrm{mg} / \mathrm{L}$ in February) and the highest $\mathrm{Mn}$ mean concentration $(0.135 \pm 0.068 \mathrm{mg} / \mathrm{L})$ for the period of February to July 2011. That water had pH 6.1 in February, the lowest $\mathrm{pH} 5.6$ in March and the highest pH 6.4 in July with a mean $\mathrm{pH}$ of $6.1 \pm 0.3$ for the period of February to July.

$\mathrm{Mn}$ is an essential element necessary for normal metabolism of amine acids, lipids, proteins and carbohydrates [33, 34]. Mn deficiency is rare, the body $\mathrm{Mn}$ needs being insured by the daily food intake through retention of $3 \%$ to $5 \%$ of ingested $\mathrm{Mn}$. The nervous system is the main organ target of $\mathrm{Mn}$. Exposure to low Mn concentrations leads to subtle changes, particularly in motor functions and humor, and exposure to high Mn levels leads to manganism, a degenerative neurological disorder with a lot of similarities with the Parkinson's disease [34, 35]. Till recently, less attention was turned to $\mathrm{Mn}$ in drinking water but reports suggesting increased infantile mortality [36], intellectual deficiencies [37], and increased hyperactive behavior in children [38] associated with high $\mathrm{Mn}$ concentrations in drinking water have increased new worries on $\mathrm{Mn}$ in drinking water. The fact that one may observe signs and mechanisms of evolution of clinical symptoms of the Parkinson's syndrome in cases of $\mathrm{Mn}, \mathrm{Fe}, \mathrm{Cu}$ and $\mathrm{Zn}$ poisoning as well as in cases of intoxication by carbon monoxide and $\mathrm{Mg}$ deficiency has drawn attention on the role of heavy metals in that context [39-41].

\subsubsection{Molybdenum (Mo)}

Mo was not detected in most (77\%) analyzed water samples. Mo concentrations did not exceed 0.001 $\mathrm{mg} / \mathrm{L}$ in faucet water and they ranged from $0-0.009$ $\mathrm{mg} / \mathrm{L}$ in spade-sunk well water and from 0-0.002 $\mathrm{mg} / \mathrm{L}$ in drilled well water (Table 10). Those Mo concentrations were lower than the $0.07 \mathrm{mg} / \mathrm{L}$ WHO [6] maximum permissible Mo concentration limit in drinking water. It has been reported that Mo concentrations in groundwater are generally very low [41-43].

\subsubsection{Nickel (Ni)}

$\mathrm{Ni}$ was not detected in all faucet water samples and in spade-sunk well EPA8 and drilled well EPP2 water samples. The Ni levels of water from the other spade-sunk wells $(0-0.008 \mathrm{mg} / \mathrm{L})$ and drilled wells $(0-0.027 \mathrm{mg} / \mathrm{L})$ in the Kipushi mining town were very low and lower than the $0.07 \mathrm{mg} / \mathrm{L}$ WHO [6] maximum permissible $\mathrm{Ni}$ concentration limit in drinking water (Table 11).

The human body needs small quantities of $\mathrm{Ni}$ to produce blood red cells. However, excessive Ni quantities may gradually become toxic. Short-term Ni overexposure does not cause any health problem but long-term exposure may cause body weight loss, heart and liver damages, and skin irritation [14]. Ingestion of

Table 10 Mean values and standard deviations of $\mathrm{pH}$ and Mo levels of supply water and well water in Kipushi in 2011, and the WHO [6] guidelines.

\begin{tabular}{lll}
\hline & $\begin{array}{l}\text { WHO* drinking water pH optimum and } \\
\text { maximum permissible Mo concentration }\end{array}$ \\
& $\begin{array}{l}\text { limit, and Mo mean concentration values } \\
\text { with standard deviation of the water samples }\end{array}$ \\
\cline { 2 - 3 } & $\mathrm{pH}$ & \multicolumn{1}{c}{ Mo $(\mathrm{mg} / \mathrm{L})$} \\
\hline WHO* & $6.5-9.5$ & 0.07 \\
guidelines & & \\
water sample & & $\mathrm{ND}$ \\
EDD1 & $7.4 \pm 0.1$ & $0.001 \pm 0$ \\
EDD2 & $7.2 \pm 0.1$ & $\mathrm{ND}$ \\
EPA1 & $5.7 \pm 0.2$ & $\mathrm{ND}$ \\
EPA2 & $6.9 \pm 0.2$ & $0.001 \pm 0.001$ \\
EPA3 & $6.5 \pm 0.2$ & $0.001 \pm 0.001$ \\
EPA4 & $6.8 \pm 0.1$ & $\mathrm{ND}$ \\
EPA5 & $6.0 \pm 0.1$ & $0.001 \pm 0.001$ \\
EPA6 & $5.8 \pm 0.1$ & $0.002 \pm 0.004$ \\
EPA7 & $6.4 \pm 0.2$ & $\mathrm{ND}$ \\
EPA8 & $5.6 \pm 0.3$ & $\mathrm{ND}$ \\
EPA9 & $7.4 \pm 0.1$ & $0.001 \pm 0.001$ \\
EPP1 & $6.5 \pm 0.2$ & $0.0003 \pm 0.0005$ \\
EPP2 & $6.9 \pm 0.1$ & $\mathrm{ND}$ \\
EPP3 & $6.3 \pm 0.2$ & $\mathrm{ND}$ \\
EPP4 & $6.1 \pm 0.1$ & $\mathrm{ND}$ \\
EPP5 & $6.1 \pm 0.3$ &
\end{tabular}

* WHO: World Health Organization, ND: not detected. 
Table 11 Mean values and standard deviations of $\mathrm{pH}$ and Ni levels of supply water and well water in Kipushi in 2011, and the WHO [6] guidelines.

\begin{tabular}{lll}
\hline & \multicolumn{2}{l}{$\begin{array}{l}\text { WHO* drinking water } \mathrm{pH} \text { optimum and } \\
\text { maximum permissible Ni concentration } \\
\text { limit, and Ni mean concentration values }\end{array}$} \\
& $\begin{array}{l}\text { with standard deviation of the water samples } \\
\text { Ph }\end{array}$ \\
\hline WHO* & $6.5-9.5$ & 0.07 \\
guidelines & & \\
water sample & & $\mathrm{ND}$ \\
EDD1 & $7.4 \pm 0.1$ & $\mathrm{ND}$ \\
EDD2 & $7.2 \pm 0.1$ & $0.001 \pm 0.001$ \\
EPA1 & $5.7 \pm 0.2$ & $0.001 \pm 0.001$ \\
EPA2 & $6.9 \pm 0.2$ & $0.001 \pm 0.001$ \\
EPA3 & $6.5 \pm 0.2$ & $0.001 \pm 0.001$ \\
EPA4 & $6.8 \pm 0.1$ & $0.001 \pm 0.001$ \\
EPA5 & $6.0 \pm 0.1$ & $0.001 \pm 0.001$ \\
EPA6 & $5.8 \pm 0.1$ & $0.002 \pm 0.003$ \\
EPA7 & $6.4 \pm 0.2$ & $\mathrm{ND}$ \\
EPA8 & $5.6 \pm 0.3$ & $0.001 \pm 0.001$ \\
EPA9 & $7.4 \pm 0.1$ & $0.001 \pm 0.002$ \\
EPP1 & $6.5 \pm 0.2$ & $\mathrm{ND}$ \\
EPP2 & $6.9 \pm 0.1$ & $0.001 \pm 0.001$ \\
EPP3 & $6.3 \pm 0.2$ & $0.004 \pm 0.003$ \\
EPP4 & $6.1 \pm 0.1$ & $0.014 \pm 0.013$ \\
EPP5 & $6.1 \pm 0.3$ &
\end{tabular}

* WHO: World Health Organization, ND: not detected.

high Ni quantities may also cause cancer, respiratory arrest, abortions, allergies and cardiac arrest [45]. The phagocytosis of $\mathrm{Ni}$ compound particles and their dissolution in the nucleus induces an oxidative stress with genetic mutation [46].

\subsubsection{Zinc (Zn)}

$\mathrm{Zn}$ concentrations in faucet water $(0.016-0.17 \mathrm{mg} / \mathrm{L})$ and those in spade-sunk well water (0.001-0.25 mg/L) were lower than the $3 \mathrm{mg} / \mathrm{L}$ WHO [6] maximum permissible $\mathrm{Zn}$ concentration limit in drinking water (Table 12) and were similar to the $\mathrm{Zn}$ concentrations found in boreholes and hand dug wells in Ife area (Nigeria) by Jeje and Oladepo [47].

In drilled well water, concentrations of that metal ranged from $0.016-5.52 \mathrm{mg} / \mathrm{L}$. The $\mathrm{Zn}$ concentrations in water from the EPP1 and EPP4 drilled wells in February $(5.52 \mathrm{mg} / \mathrm{L}$ and $3.91 \mathrm{mg} / \mathrm{L}$ respectively) were higher than the $3 \mathrm{mg} / \mathrm{L}$ WHO maximum
Table 12 Mean values and standard deviations of $\mathrm{pH}$ and Zn levels of supply water and well water in Kipushi in 2011, and the WHO [6] guidelines.

\begin{tabular}{llc}
\hline & \multicolumn{2}{l}{$\begin{array}{l}\text { WHO* drinking water } \mathrm{pH} \text { optimum and } \\
\text { maximum permissible } \mathrm{Zn} \text { concentration } \\
\text { limit, and Zn mean concentration values }\end{array}$} \\
& $\begin{array}{l}\text { with standard deviation of the water samples } \\
\text { pH }\end{array}$ \\
\hline WHO* & $6.5-9.5$ & \multicolumn{2}{l}{$\mathrm{Zn}(\mathrm{mg} / \mathrm{L})$} \\
guidelines & & 3 \\
water sample & & $0.126 \pm 0.047$ \\
EDD1 & $7.4 \pm 0.1$ & $0.029 \pm 0.01$ \\
EDD2 & $7.2 \pm 0.1$ & $0.065 \pm 0.026$ \\
EPA1 & $5.7 \pm 0.2$ & $0.023 \pm 0.023$ \\
EPA2 & $6.9 \pm 0.2$ & $0.032 \pm 0.008$ \\
EPA3 & $6.5 \pm 0.2$ & $0.113 \pm 0.043$ \\
EPA4 & $6.8 \pm 0.1$ & $0.136 \pm 0.063$ \\
EPA5 & $6.0 \pm 0.1$ & $0.034 \pm 0.006$ \\
EPA6 & $5.8 \pm 0.1$ & $0.038 \pm 0.023$ \\
EPA7 & $6.4 \pm 0.2$ & $0.056 \pm 0.022$ \\
EPA8 & $5.6 \pm 0.3$ & $0.023 \pm 0.038$ \\
EPA9 & $7.4 \pm 0.1$ & $1.771 \pm 2.199$ \\
EPP1 & $6.5 \pm 0.2$ & $0.34 \pm 0.691$ \\
EPP2 & $6.9 \pm 0.1$ & $0.208 \pm 0.133$ \\
EPP3 & $6.3 \pm 0.2$ & $2.17 \pm 0.859$ \\
EPP4 & $6.1 \pm 0.1$ & $0.593 \pm 0.469$ \\
EPP5 & $6.1 \pm 0.3$ &
\end{tabular}

* WHO: World Health Organization.

permissible $\mathrm{Zn}$ concentration limit in drinking water, but the mean $\mathrm{Zn}$ concentrations in water from those two wells $(1.771 \pm 2.199 \mathrm{mg} / \mathrm{L}$ and $2.17 \pm 0.859 \mathrm{mg} / \mathrm{L}$, respectively) and the other wells were lower than the WHO maximum permissible $\mathrm{Zn}$ concentration limit in drinking water (Table 12).

The source of $\mathrm{Zn}$ high content in drilled well water seems to be the host rock and/or soil infiltration of that metal from the surface to the groundwater table.

\section{Conclusion}

Levels of eleven heavy metals $(\mathrm{Al}, \mathrm{Cd}, \mathrm{Co}, \mathrm{Cr}, \mathrm{Cu}$, $\mathrm{Fe}, \mathrm{Mn}, \mathrm{Mo}, \mathrm{Ni}, \mathrm{Pb}$ and $\mathrm{Zn}$ ) and $\mathrm{pH}$ of water from two water supply faucets, nine spade-sunk wells and five drilled wells in the Kipushi mining town were investigated from February to July 2011 to know the chemical quality of the water consumed by the population of that town. The results were compared with the WHO $\mathrm{pH}$ and heavy metal guidelines for 
drinking water. Supply water was in accordance with the WHO $\mathrm{pH}$ optimum and heavy metal maximum permissible limits for drinking water, except $\mathrm{Pb}$ concentrations in water samples from one of the water supply faucets which were higher than the WHO $\mathrm{Pb}$ maximum permissible concentration limit of 0.01 $\mathrm{mg} / \mathrm{L}$. Waters from only two over fourteen wells were in accordance with the WHO pH optimum and heavy metal guidelines for drinking water. The $\mathrm{pH}$ of water of five spade-sunk wells and two drilled wells was slightly acid, lower than 6.5. Water of only four spade-sunk wells and two drilled wells was good for human consumption in view of their $\mathrm{pH}$ values. $\mathrm{Al}$ in water of six spade-sunk wells, $\mathrm{Cd}$ in water of three drilled wells, $\mathrm{Fe}$ in water of five spade-sunk wells, $\mathrm{Mn}$ in water of two spade-sunk wells and three drilled wells, and $\mathrm{Zn}$ in two drilled wells were the heavy metals of which levels were periodically higher than the WHO heavy metal maximum permissible concentration limits in drinking water.

The high concentrations of those metals in water in the Kipushi mining town mainly came from the tailings stocked at the surface in that town and from interaction between groundwater and those metals found in high or less concentrations in the subsoil. The physical and chemical instability of those tailings has a negative impact on the closest surrounding environments (natural rivers, underlying soils, groundwater tables etc.) by migration and dispersion of the heavy metals.

Due to high concentrations of certain heavy metals in faucet and well waters in the Kipushi mining town, the population consuming those waters runs a health risk. Further investigations on heavy metal contamination of groundwater in Kipushi are necessary to keep on assessing the chemical quality of that water consumed by the local population.

\section{Acknowledgements}

The authors thank GECAMINES for its authorization to access its premises. Robinson
International in Africa in Lubumbashi is thanked for performing chemical analyses of the water samples.

\section{References}

[1] World Health Organization. "Health Through Safe Drinking Water and Basic Sanitation: Goal 7, Target 10 of the Millennium Development Goals Aims to Halving by 2015 the Proportion of People Without Sustainable Access to Safe Drinking Water and Basic Sanitation.” Accessed October 15, 2015. http://www.who.int/water_sanitation_health/mdg1/en/.

[2] United Nations Environmental Program (UNEP). 2011. Water Issues in DRC: Challenges and Opportunities. Technical report.

[3] Intiomale, M. M., and Oosterbosch, R. 1974. "Geology and Geochemistry of the Kipushi (Zaire) Stratiformous Deposits." In Stratiformous Deposits and Cupriferous Provinces, edited by Bartolome, P. Belgium: Geological Society.

[4] Kitobo, W., Kalenga, P., Ilunga, N. A., Luboya, O., and Funay, J. 2007. "Characterization of the Mobility of Metallic Trace Elements Contained in the Waste of the Kipushi Old Concentrator in D.R. Congo." Annals of The Mines-Geology Pole 1: 133-142.

[5] Kitobo, W. 2009. "Depollution/Decontamination and Valorization of Sulphuratted Mining Waste of Katanga: Case of the Kipushi Old Concentrator Tailings.” Ph.D. thesis, Liege University.

[6] World Health Organization. 2008. Guidelines for Drinking-Water Quality (Electronic Source), 3rd Edition Incorporating the First and Second Addenda. Geneva: WHO.

[7] Adepoju-Bello, A. A., and Alabi, O. M. 2005. "Heavy Metals: A Review." The Nigerian Journal of Pharmacology 37: 41-45.

[8] Jarup, L. 2003. "Hazards of Heavy Metal Contamination." British Medical Bulletin 68: 167-82.

[9] Martin, S., and Griswold, W. 2009. "Human Health Effects of Heavy Metals." Environmental Science and Technology Briefs for Citizens 15: 1-5.

[10] Zietz, B. P., Lap, J., and Suchenwirth, R. 2007. "Assessment and Management of Tap Water Lead Contamination in Lower Saxon, Germany." International Journal of Environmental Health Research 17 (6): 407-418.

[11] Needleman, H. L. 1993. "The Current Status of Childhood Low-Level Lead Toxicity.” Neurotoxicology 14: 181-166.

[12] Yule, W., and Rutter, M. 1985. "Behavior and Cognitive Performance: A Critical Review." In Dietary and Environmental Lead (Pb): Human Health Effects, edited 
by Mahaffey, R. New York: Elsevier.

[13] Glover-Kerkvliet, J. 1995. "Environmental Assault on Immunity." Environmental Health Perspectives 103 (3): $236-239$.

[14] Lenntech, B. V. "Heavy Metals." Accessed October 15, 2015.

http://www.lenntech.com/processes/heavy/heavy-metals/ heavy-metals.htm.

[15] Dr. Edward Group DC, NP, DACBN, DABFM. 2013. "The Effects of Toxic Metals." Accessed October 15, 2015. http://www.globalhealingcenter.com/natural-health/effect s-of-toxic-metals/.

[16] Monsieur, R. "Toxic Metals, Pathologies Related to Heavy Metals.” Accessed October 16, 2015. http://natural-medicine.labosp.com/List_of_scientific_stu dies/Toxic_metals_pathologies_related_to_heavy_metals. doc.php.

[17] Iqbal, M. A., and Gupta, S. G. 2009. "Studies on Heavy Metal Ion Pollution of Groundwater Sources as An Effect of Municipal Solid Waste Dumping." African Journal of Basic \& Applied Sciences 1 (5-6): 117-122.

[18] Makkasap, T., and Satapanajaru, T. 2010. "Spatial Distribution of $\mathrm{Cd}, \mathrm{Zn}$ and $\mathrm{Hg}$ in Groundwater at Rayong Province, Thailand." World Academy of Science, Engineering and Technology 72: 826-829.

[19] Akoteyon, I. S., Mbata, U. A., and Olalude, G. A. 2011. "Investigation of Heavy Metal Contamination in Groundwater around Landfill Site in a Typical Sub-urban Settlement in Alimosho, Lagos, Nigeria." Journal of Applied Sciences in Environmental Sanitation 6 (2): 155-163.

[20] Meranger, J. C., Subramanian, K. S., and Chalifoux, C. 1979. "A National Survey for Cadmium, Chromium, Copper, Lead, Zinc, Calcium and Magnesium in Canadian Drinking Water Supplies.” Environmental Science and Technology 13 (6): 707-711.

[21] Hotz, P., Buchet, J. P., Bernard, A., Lison, D., and Lauwerys, R. 1999. "Renal Effects of Low-level Environmental Cadmium Exposure: 5-Year Follow-up of a Subcohort from the Cadmibel Study." The Lancet 354: 1508-1513.

[22] Järup, L., Berglund, M., Elinder, C. G., Nordberg, G., and Vahter, M. 1998. "Health Effects of Cadmium Exposure-A Review of the Literature and a Risk Estimate." Scandinavian Journal of Work, Environment \& Health 24 (Suppl. 1): 1-51.

[23] World Health Organization. 1992. Cadmium. Environmental Health Criteria. Geneva: WHO.

[24] Miquel, G., 2001. "Environmental and Health Effects of Heavy Metals." Accessed October 16, 2015. http://www.senat.fr/rap/100-261/100-261.html.
[25] Lenntech B. V. "Chemical Properties of Cadmium-Health and Environmental Effects of Cadmium." Accessed October 16, 2015. http://www.lenntech.com/periodic/elements/cd.htm.

[26] Agency for Toxic Substances and Disease Registry (ATSDR). 1992. Toxicological Profile for Cobalt. U.S: Department of Health and Human Services.

[27] California Environmental Protection Agency (Cal. EPA). 1997. Technical Support Document for the Determination of Noncancer Chronic Reference Exposure Levels, Draft for Public Comment. Berkeley (CA): Office of Environmental Health Hazard Assessment.

[28] U.S. Department of Health and Human Services. 1993. Hazardous Substances. Bethesda (MD): National Toxicology Information Program, National Library of Medicine.

[29] United States Environmental Protection Agency. "Basic Information about Chromium in Drinking Water." Accessed October 16, 2015. http://www.epa. gov/drink/contaminants/basicinformation/chromium.cfm.

[30] Sutton, R. 2010. "Cancer-Causing Chromium-6 Pollution in U.S. Tap Water." Environmental Work Group. Accessed October 16, 2015. http://www.ewg.org/chromium6-in-tap-water.

[31] Desai, V., and Kaler, S. G. 2008. "Role of Copper in Human Neurological Disorders." American Journal of Clinical Nutrition 88 (3): 855S-858S.

[32] Madsen, E., and Gitlin, J. D. 2007. "Copper and Iron Disorders of the Brain." Annual Reviews of Neuroscience 30: 317-337.

[33] Lions, J. 2004. "Hydrogeochemical Study of the Mobility of Inorganic Pollutants in the Cleaning out of Sediment Deposit; Experimentations, in Situ Studies and Modelling." Ph.D. thesis, Paris National Superior School of Mines.

[34] Erikson, K. M., Thomson, K., Aschner, J., and Aschner, M. 2007. "Manganese Neurotoxicity: A Focus on the Neonate." Pharmacology and Therapeutics 113 (2): 369-377.

[35] Bowman, A. B., Kwakye, G. F., Herrero Hernandez E., and Aschner, M. 2011. "Role of Manganese in Neurodegenerative Diseases." Journal of Trace Elements in Medicine and Biology 25 (4): 191-203.

[36] Mergler, D., and Baldwin, M. 1997. "Early Manifestations of Manganese Neurotoxicity in Humans: An Update.” Environmental Research 73: 92-100.

[37] Hafeman, D., Factor-Litvak, P., Cheng, Z., Van-Geen, A., and Ahsan, H. 2007. "Association between Manganese Exposure through Drinking Water and Infant Mortality in Bangladesh." Environmental Health Perspectives 115: 1107-1112.

[38] Wasserman, G., Liu, X., Parvez, F., Ahsan, H., Levy, D., 
and Factor-Litvak, P. 2006. "Water Manganese Exposure and Environmental Children's Intellectual Function in Araihazar, Bangladesh." Health Perspectives 114: 124-129.

[39] Bouchard, M., Laforest, F., Vandelac, L., Bellinger, D., and Mergler, D. 2007. "Hair Manganese and Hyperactive Behaviors: Pilot Study of School-age Children Exposed through Tap Water." Environmental Health Perspectives 115: 122-127.

[40] Aschner, M., and Dorman, D. C. 2006. "Manganese: Pharmacokinetics and Molecular Mechanism of Brain Uptake.” Toxicological Review 25 (3): 147-154.

[41] Aschner, M., Erikson, K. M., Hernandez, E. H., and Tjalkens, R. 2009. "Manganese and Its Role in Parkinson's Disease from Transport to Neuropathology." Neuromolecular Medicine 11 (4): 252-266.

[42] Barceloux, D. G., and Barceloux, D. 1999. "Molybdenum." Journal of Toxicology: Clinical Toxicology 37 (2): 231-237.

[43] Smedley, P. L., Cooper, D. M., Ander, E. L., Milne, C. J., and Lapworth, D. J. 2014. "Occurrence of Molybdenum in British Surface Water and Groundwater: Distribution, Controls and Implications for Water Supply." Applied Geochemistry 40: 144-154.

[44] Hensel, B. R., Jansen, T. J., and Muehlfeld, T. C. 2015. "Groundwater Forensics to Evaluate Molybdenum concentrations Near a CCR Landfill." In 2015 World of Coal Ash (WOCA) Conference, 14.

[45] Fukushima, T., Tan, X., Luo, Y., and Kanda, H. 2010. "Relationship between Blood Levels of Heavy Metals and Parkinson's Disease in China." Neuroepidemiology 34 (1): 18-24.

[46] Lenntech B. V. "Chemical Properties of Nickel—Health Effects of Nickel-Environmental Effects of Nickel." Accessed October 16, 2015. http://www.lenntech.com/periodic-chart-elements/Ni-en.h tm.

[47] Jeje, J. O., and Oladepo, K. T. 2014. "Assessment of Heavy Metals of Boreholes and Hand Dug Wells in Ife North Local Government Area of Osun State, Nigeria." International Journal of Science and Technology 3 (4): 209-214. 